\title{
Dining out with commoners: queens of Camponotus novogranadensis Mayr, 1870 (Hymenoptera: Formicidae) feeding outside the nest with nestmate workers Jantando fora com os plebeus: rainhas de Camponotus novogranadensis Mayr, 1870 (Hymenoptera: Formicidae) alimentando-se fora do ninho com operárias
}

\author{
Fernando da Silva Carvalho-Filho (1) \\ Museu Paraense Emílio Goeldi/MCTIC. Belém, Pará, Brasil
}

\begin{abstract}
An ant colony usually shows a division into reproductive (queens and alate males) and nonreproductive (workers and soldiers) castes. In most ant species, the tasks outside of a mature colony are performed predominately by the non-reproductive castes, and the reproductive queens usually do not leave the nest after founding. Therefore, queens are feed by workers that, upon returning to the nest, regurgitate a portion of stored fluid. However, queens of Camponotus novogranadensis Mayr, 1870 were recorded feeding on the carcass of a mourning gecko outside the nest with nestmate major and minor workers in a disturbed habitat in Belém, Pará state, northern Brazil.
\end{abstract}

Keywords: Eusociality. Insecta. Polygyny. Claustral founding.

Resumo: Nas colônias de formigas, há uma divisão em castas reprodutivas (rainhas e machos) e não reprodutivas (operárias e soldados). Na maioria das espécies de formigas, as tarefas externas de uma colônia madura são predominantemente desempenhadas pelas castas não reprodutivas, uma vez que as rainhas reprodutivas geralmente não saem do ninho. As rainhas são, portanto, alimentadas pelas operárias que, ao retornarem ao ninho, regurgitam uma parte do alimento fluido armazenado em seus corpos. No entanto, nesta nota, rainhas de Camponotus novogranadensis Mayr, 1870 foram registradas alimentando-se da carcaça de uma lagartixa fora do ninho junto com as operárias do mesmo ninho, em uma área antropizada em Belém, estado do Pará, Norte do Brasil.

Palavras-chave: Eusocialidade. Insecta. Poligenia. Fundação claustral.

CARVALHO-FILHO, F. S., 2020. Dining out with commoners: queens of Camponotus novogranadensis Mayr, 1870 (Hymenoptera: Formicidae) feeding outside the nest with nestmate workers. Boletim do Museu Paraense Emílio Goeldi. Ciências Naturais 15(1): 227-230. DOI: http://doi.org/10.46357/bcnaturais.v15i1.282.

Autor para correspondência: Fernando da Silva Carvalho-Filho. Av. Perimetral, 1901 - Terra Firme. Belém, PA, Brasil. CEP 66077-530 (fernandofilho@museu-goledi.br).

Recebido em 18/02/2020

Aprovado em 01/04/2020

Responsabilidade editorial: Lívia Pires do Prado 


\section{INTRODUCTION}

Ants (Formicidae) are highly successful insects, constituting $15 \%$ to $25 \%$ of the all terrestrial animal biomass (Schultz, 2000). They are distributed in a great variety of microhabitats in terrestrial ecosystems, such as in soil, leaf litter, fallen trunks and twigs, abandoned or active nests of other social insects, living trees and forest canopy (Hölldobler \& Wilson, 1990).

The evolutionary success of ants is mainly attributed to their eusociality, an evolutionarily advanced level of colonial existence present in all species of formicids (Hölldobler \& Wilson, 1990), characterized by the simultaneous presence of two or more overlapping generations of adults within a colony; cooperative brood care (individuals care for brood that is not their own); and division into reproductive and nonreproductive (or at least less-reproductive) castes (Hölldobler \& Wilson, 1990).

In most ant species, the tasks performed external to the nest in mature colonies are predominately done by the non-reproductive castes of workers and soldiers, since the reproductive queens usually do not leave the nest (Brown \& Bonhoeffer, 2003). The queens only exit their nest during migration of the colony to a new nest or to found a new colony. However, in some species of the subfamilies Myrmeciinae, Nothomyrmecinae, most of "Poneromorph" subfamilies and some Formicinae and Myrmicinae, that have a semi- or a partially claustral nest foundation, the queens, during the colony-founding, also forage for food with which to provision their first brood (Brown \& Bonhoeffer, 2003 and references therein). In mature colonies the queens are thus feed by workers that, upon returning to the nest, regurgitate a portion of food fluid carried in the proventriculus (Hölldobler \& Wilson, 1990).

Ants usually are predators or scavengers, feeding on a wide range of prey, mainly arthropods, but there are species that also consumes seeds or fungi (Hölldobler \& Wilson, 1990). Adults usually feed on liquid substances, such as sugary substances produced by plants and insects of the orders Auchenorrhyncha (such as treehoppers) and
Stenorrhyncha (such as aphids, mealybugs, etc.), but they have been observed feeding on urine, feces, and vertebrate carcasses, that are an important source of additional nutrients, mainly to herbivorous species (Petit et al., 2019).

In contrast to expected ant behavior, a group of workers and queens of the same colony were observed feeding together in a gecko carcass outside the nest in an urban area.

\section{MATERIAL AND METHODS}

The observation reported in this study was made in the courtyard of a residence located in an urban area of Belém, state of Pará, Brazil. In total, one and a half hours of observations were made. Some ants (workers, soldiers and queens) were collected and deposited in the entomological collection of the Museu Paraense Emilio Goeldi (MPEG), Belém, state of Pará, Brazil. Specimens were identified by a specialist from the MPEG.

Photographs were taken with a Nikon D90 camera with a Sigma 105 mm macro lens and a Nikon SB900 flash bearing a homemade diffuser.

\section{RESULTS AND DISCUSSION}

On December 20, 2019, a group of about 30 ants (Camponotus novogranadensis Mayr, 1870) were observed feeding on the fresh carcass of a mourning gecko (Lepidodactylus lugubris (Duméril \& Bibron, 1836)) in the evening (1800 h) (Figure 1). The gecko was killed and partially consumed by a domestic cat the previous night. The group of ants was composed of two dealated queens, minor and major workers (Figure 1). Like the workers, the queens were also observed licking the exposed tissue of the gecko carcass. The ants were not observed chewing and removing pieces of tissue, nor were they returning with it to the nest, whose entrance, a small hole in the wall of a residence about five centimeters above the ground, was located about 70 centimeters from the carcass. One of the queens returned to the nest after 40 minutes of observation and the other after an hour and 20 minutes. 


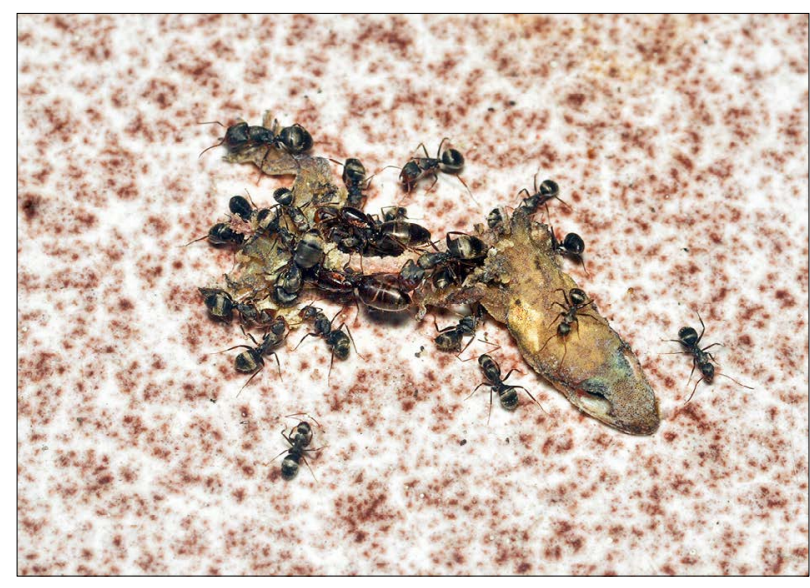

Figure 1. Dealate queens, soldiers, and workers of Camponotus novogranadensis feeding on the fresh carcass of a mourning gecko (Lepidodactylus lugubris) in an urban area of Belém, state of Pará, Brazil. Photo: F. S. Carvalho-Filho (2019).

There is little information on the biology of $C$. novogranadensis, even though it is widespread in the neotropics and was recently recorded for the first time in Florida, USA (Deyrup \& Belmont, 2013). This species has been recorded as part of the urban and even domestic fauna of northern Brazil (Albuquerque \& Prado, 2017). It has been recorded feeding on honeydew produced by treehoppers (Membracidae and Aetalionidae) (Letourneau \& Choe, 1987), and nectar from extrafloral nectaries of plants (Schoereder et al., 2010). This species also is attracted to animal protein utilized as bait in traps (Vasconcelos, 1999).

Ants visit vertebrate carcasses to capture eggs, larvae, and pupae of necrophagous insects or to feed on exudates or decomposing tissues (Moretti \& Ribeiro, 2006). The specimens observed in this study were only feeding on exudates and tissues, and larvae and eggs of carrion flies were not observed on the gecko carcass.

Urine, bird feces, and vertebrate carcasses may represent an important nitrogen sources for ants, mainly to herbivorous species that usually do not have access to this nutrient by means of usual food (Petit et al., 2019), such as C. novogranadensis that feeds predominately on honeydew (Schoereder et al., 2010). However, carcasses are ephemeral and not a common source of food as is honeydew, becoming very attractive to ants so that even to the queens leave the nest to consume it.

The queen of most Camponutus species exhibit claustral nest foundation, such that they never leave the nest for foraging (Brown \& Bonhoeffer, 2003). The evolutionary advantage attributed to claustral foundation in ants is that it reduces queen mortality by predation (Hölldobler \& Wilson, 1990; Brown \& Bonhoeffer, 2003). The loss of some foraging $C$. novogranadensis queens outside of the nest may not represent a severe risk to the colony since, like other Camponotus species, this species is polygynic (Akre et al., 1994).

\section{ACKNOWLEDGMENTS}

I would like to thank Livia Pires do Prado, who identified the ants, and Dr. William L. Overal for reviewing the manuscript.

\section{REFERENCES}

AKRE, R. D., L. D. HANSEN \& E. A. MYHRE, 1994. Colony size and polygyny in carpenter ants (Hymenoptera: Formicidae). Journal of the Kansas Entomological Society 67(1): 1-9.

ALBUQUERQUE, E. Z. \& L. P. PRADO, 2017. Formigas em ambientes urbanos na região Norte: o estado da arte e perspectivas futuras. In: O. C. BUENO, A. E. C. CAMPOS \& M. S. C. MORINI (Ed.): Formigas em ambientes urbanos do Brasil: 523-551. Canal 6, Bauru.

BROWN, M. J. F. \& S. BONHOEFFER, 2003. On the evolution of claustral colony founding in ants. Evolutionary Ecology Research 5: 305-313.

DEYRUP, M. \& R. A. BELMONT, 2013. First record of a Florida population of the Neotropical carpenter ant Camponotus novogranadensis (Hymenoptera: Formicidae). Florida Entomologist 96(1): 283-285. DOI: http://doi.org/10.1653/024.096.0148.

HÖLLDOBLER, B. \& E. O. WILSON, 1990. The ants: 1-732. Harvard University Press, Cambridge.

LETOURNEAU, D. K. \& J. C. CHOE, 1987. Homopteran attendance by wasps and ants: the stochastic nature of interactions. Psyche: A Journal of Entomology 94: 81-91. DOI: https://doi. org/10.1155/1987/12726.

MORETTI, T. C. \& O. B. RIBEIRO, 2006. Cephalotes clypeatus Fabricius (Hymenoptera: Formicidae): hábitos de nidificação e ocorrência em carcaça animal. Neotropical Entomology 35(3): 412-415. DOI: https://doi.org/10.1590/S1519-566X2006000300019.

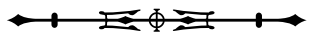


PETIT, S., M. B. STONOR, J. J. WEYLAND, J. GIBBS \& B. AMATO, 2019. Camponotus ants mine sand for vertebrate urine to extract nitrogen. Austral Ecology 45(2): 168-176. DOI: http://doi. org/10.1111/aec.12840.

SCHOEREDER, J. H., T. G. SOBRINHO, M. S. MADUREIRA, C. R. RIBAS \& P. S. OLIVEIRA, 2010. The arboreal ant community visiting extrafloral nectaries in the Neotropical cerrado savana. Terrestrial Arthropod Reviews 3(1): 3-27. DOI: https://doi. org/10.1163/187498310X487785.
SCHULTZ, T. R., 2000. In search of ant ancestors. Proceedings of the National Academy of Sciences 97(26): 14028-14029. DOI: https://doi.org/10.1073/pnas.011513798.

VASCONCELOS, H. L., 1999. Effects of forest disturbance on the structure of ground-foraging ant communities in central Amazonia. Biodiversity and Conservation 8: 407-418. DOI: https://doi. org/10.1023/A:1008891710230. 